\title{
Perineal trauma after vaginal delivery in healthy pregnant women
}

\author{
Trauma perineal após parto vaginal em parturientes saudáveis
}

\author{
Larissa Santos Oliveira', Luiz Gustavo Oliveira Brito", Silvana Maria Quintana"'I, Geraldo Duarte" ${ }^{\mathrm{I}}$, Alessandra Cristina Marcolin ${ }^{\vee}$ \\ Obstetrics \& Urogynecology Division, Department of Gynecology and Obstetrics, Faculdade de Medicina de Ribeirão Preto (FMRP), \\ Universidade de São Paulo (USP), and Centro de Referência em Saúde da Mulher de Ribeirão Preto (MATER), Ribeirão Preto, São Paulo, Brazil
}

'MD. Physician, Department of Gynecology and Obstetrics, Faculdade de Medicina de Ribeirão Preto (FMRP), Universidade de São Paulo (USP), Ribeirão Preto, São Paulo, Brazil.

"MD, PhD. Attending Physician, Department of Gynecology and Obstetrics, Faculdade de Medicina de Ribeirão Preto (FMRP), Universidade de São Paulo (USP), Ribeirão Preto, São Paulo, Brazil. "'MD, PhD. Associate Professor, Department of Gynecology and Obstetrics, Faculdade de Medicina de Ribeirão Preto (FMRP), Universidade de São Paulo (USP), Ribeirão Preto, São Paulo, Brazil. "MD, PhD. Full Professor, Department of Gynecology and Obstetrics, Faculdade de Medicina de Ribeirão Preto (FMRP), Universidade de São Paulo (USP), Ribeirão Preto, São Paulo, Brazil. 'MD, PhD. Professor, Department of Gynecology and Obstetrics, Faculdade de Medicina de Ribeirão Preto (FMRP), Universidade de São Paulo (USP), Ribeirão Preto, São Paulo, Brazil.

\section{KEY WORDS:}

Lacerations.

Labor stage, second.

Postural balance.

Episiotomy.

Obstetrical forceps.

\section{PALAVRAS-CHAVE:}

Lacerações.

Segunda fase do trabalho de parto.

Equilíbrio postural.

Episiotomia.

Forceps obstétrico.

\begin{abstract}
CONTEXT AND OBJECTIVE: Despite all the medical care provided during delivery labor, perineal injury is still prevalent and may lead to diverse pelvic floor disorders. The aim here was to investigate the prevalence of obstetric and anal sphincter injuries (OASIS) in healthy pregnant women after vaginal delivery. DESIGN AND SETTING: Cross-sectional study involving 3,034 patients with singletons in a secondary hospital for low-risk cases.

METHODS: A standardized questionnaire was prepared and applied to medical files that had been completely filled out (classification of the Royal College of Obstetricians and Gynecologists, RCOG) in order to identify OASIS and analyze risk factors associated with mild and severe perineal lacerations.

RESULTS: The women's mean age was 25 years; more than half (54.4\%) were primiparae. Almost 38\% of the participants had perineal lacerations; these were severe in $0.9 \%$ of the cases. Previous vaginal delivery (odds ratio, OR: 1.64 [1.33-2.04]) and forceps delivery (OR: 2.04 [1.39-2.97]) were risk factors associated with mild perineal injuries ( $1^{\text {st }}$ and $2^{\text {nd }}$ OASIS classifications). Only remaining standing for prolonged periods during professional activity (OR: 2.85 [1.34-6.09]) was associated with severe perineal injuries.

CONCLUSION: The prevalence of severe perineal injuries was concordant with data in the literature. The variable of standing position was considered to be a risk factor for severe perineal injury and should be further investigated.
\end{abstract}

\section{RESUMO}

CONTEXTO E OBJETIVOS: Apesar do cuidado médico executado durante o trabalho de parto, os traumas perineais ainda são prevalentes e podem levar a várias desordens do assoalho pélvico. O objetivo foi investigar a prevalência de injúrias obstétricas e do esfíncter anal em mulheres saudáveis após parto vaginal. DESENHO E LOCAL DE ESTUDO: Estudo transversal envolvendo 3.034 pacientes com recém-natos únicos de um hospital secundário de baixo risco.

MÉTODOS: Um questionário padronizado foi preparado e aplicado aos prontuários completamente preenchidos (classificação do Royal College of Obstetricians and Gynecologists) para identificar as lesões obstétricas e do esfíncter anal e analisar fatores de risco associados com lacerações perineais leves e graves. RESULTADOS: A média de idade das mulheres era 25 anos; mais da metade $(54,4 \%)$ era primípara. Quase 38\% das participantes tiveram lacerações perineais; estas foram graves em 0,9\% dos casos. A presença de parto vaginal prévio (odds ratio, OR, 1,64 [1,33-2,04]) e o parto fórceps (OR 2,04 [1,39-2,97]) foram fatores de risco associados às lesões perineais leves (primeira e segunda classificações de lesão esfíncter e anal). Somente a posição em pé prolongada durante a atividade profissional (OR 2,85 [1,34-6,09]) estava associada com lesões perineais graves.

CONCLUSÃO: A prevalência de trauma perineal grave concordou com dados da literatura. A variável posição em pé foi considerada fator de risco para trauma perineal grave e necessita ser investigada. 


\section{INTRODUCTION}

Perineal tears may occur after vaginal delivery. This event may lead to fecal and urinary incontinence, chronic pelvic pain and dyspareunia in young women. ${ }^{1}$ Epidemiological studies have demonstrated that perineal trauma correlates with maternal, fetal and birth delivery factors. ${ }^{1}$ Classifications for these complications have been devised ${ }^{1}$ and they have been named obstetric and anal sphincter injuries (OASIS) by urogynecologists and obstetricians.

However, the literature lacks appropriate classification systems that would predict the risks of perineal tears during obstetric care. ${ }^{2}$ Advanced maternal age, ${ }^{3,4}$ white color, ${ }^{5}$ primiparity $^{6,7}$ and obesity ${ }^{8}$ seem to be perineum-related risk factors. Heavier birth weight ${ }^{4,7}$ and persistent occipitoposterior position ${ }^{9}$ are among the fetal risk factors for perineal tears. The birth factors of prolonged second stage of labor, ${ }^{7,10}$ birth analgesia, ${ }^{11,12}$ episiotomy ${ }^{13}$ and assisted vaginal deliver $y^{4,6,7}$ increase the risk of perineal trauma.

However, it is unclear whether professional activity, administration of oxytocin and misoprostol during birth delivery and length of ruptured membranes constitute risk factors for perineal tears. Despite the current knowledge about the risk factors for severe perineal trauma, these factors depend on the type of laceration. However, investigations correlating maternal morbidity with obstetric perineal trauma are scarce.

\section{OBJECTIVE}

This study aimed to calculate the prevalence of obstetric and anal sphincter injuries during vaginal deliveries; to identify maternal, obstetric and fetal risk factors associated with perineal tears after vaginal deliveries; and to assess immediate maternal and early neonatal morbidities.

\section{METHODS}

This was a cross-sectional study that evaluated patients attended at Centro de Referência da Saúde da Mulher de Ribeirão Preto (MATER), Ribeirão Preto, São Paulo, Brazil, during 2009 and 2010. The local Ethics Committee approved this investigation, which was conducted in accordance with an institutional protocol (Department of Gynecology and Obstetrics, Ribeirão Preto School of Medicine, University of São Paulo). This hospital is a training center for residents in Obstetrics and Gynecology. Deliveries are performed by medical students and first and second-year medical residents supervised by attending physicians.

Three thousand and thirty-four women were included. The inclusion criteria were that they should have singletons with gestational age $>37$ weeks (determined according to the last menstruation period and confirmed through obstetric ultrasound), with cephalic fetal presentation, born by means of vaginal delivery and whose data were entirely recorded in the reports.
The exclusion criteria were maternal diseases (hypertension, endocrine disorders or neurological disorders), pregnancies with fetal malformation and deliveries performed outside the hospital. A questionnaire was elaborated by two physicians, in order to collect data from these women's medical files, and it was applied by a medical student.

The patients were divided into three groups: (I) patients who did not present any delivery traumas; (II) patients who presented first and second-degree (mild) perineal tears; and (III) patients who presented third and fourth-degree (severe) perineal tears. The patients' records and information about the newborns were obtained from an institutional databank. Variables relating to the patient, newborn, birth and postpartum period were obtained directly from the patient's medical records.

On the basis of a sample consisting of at least 710 patients per group, at a $5 \%$ significance level and $80 \%$ power, we estimated that the incidence of OASIS among women with a previous history of vaginal birth was $15 \%$ and $3 \%$ in primiparae and multiparae, respectively. We analyzed the following variables: (a) maternal factors: age, ethnicity, predominant posture while carrying out professional activity (standing position during work, sitting position etc.), use of tobacco and/or illicit drugs, nutritional status (maternal height and BMI) and previous vaginal birth; (b) obstetric factors: use of misoprostol to induce birth, use of oxytocin during the first and second stages of labor, length of membrane rupture, duration of second stage, presence of mediolateral episiotomy, assisted vaginal birth (forceps/vacuum) and use of locoregional analgesics; (c) fetal factors: fetal position at time of fetal expulsion, weight, skull circumference and gender of the newborn.

Perineal trauma was classified into four degrees, according to the extent of perineal and anal canal damage, following the protocol of the Royal College of Obstetricians and Gynecologists (RCOG, 2001): ${ }^{1}$ first-degree trauma was limited to the vaginal mucosa and perineal skin, second-degree trauma included the perineal musculature, third-degree trauma involved the anal sphincter, and fourth-degree trauma included the rectal mucosa.

To evaluate maternal morbidity relating to perineal trauma after birth delivery, the following parameters were considered: massive blood loss with hemodynamic instability (demanding blood transfusion or surgical approach), postpartum infection (endometritis, abscess or perineal wound infection), perineal wound dehiscence and length of hospital stay. To assess the newborns' conditions, the Apgar index, amniotic fluid conditions (presence or absence of meconium), mechanical ventilation, use of pressure support, admission to the neonatal intensive therapy unit and neonatal deaths were considered.

Using the PROC LOGISTIC program of the SAS 9.0 software (SAS Institute Inc, Cary, NC, USA), the initial statistical analysis was performed by means of the chi-square test. Simple and 
multiple logistic regression methods were used to estimate the odds ratios when the independent variable studied was binomial. Multiple and simple multinomial logistic regression was used to estimate the odds ratio when the independent variable had more than two categories. This part of the statistical analysis was conducted with the aid of the PROC CATMOD program of the SAS 9.0 software.

\section{RESULTS}

Out of a total of 3,425 records evaluated, 3,034 women fulfilled the inclusion criteria for this study: 1,650 women (54.4\%) had had previous vaginal deliveries and 1,384 (45.6\%) were having their first child. We found occurrences of mild and severe perineal trauma in $1,105(36.42 \%)$ and $27(0.9 \%)$ of the patients, respectively. Among the patients with previous vaginal births, 771 (46.7\%) presented lacerations: 759 (98.4\%) had first and second-degree lacerations and $12(1.6 \%)$ had third and fourthdegree lacerations. Among the primiparous women, 361 (26.1\%) presented perineal tears: 346 (95.8\%) presented first and second-degree tears and $15(4.2 \%)$ presented third and fourth-degree tears.

Table 1 presents the maternal, obstetric and neonatal variables of the population studied and their correlations with lacerations. The following variables influenced the type of laceration: the maternal variables of age, body position during professional activity, body mass index (BMI) and at least one previous vaginal delivery; the obstetric variables of use of oxytocin, time of membrane rupture, duration of the second period, episiotomy, locoregional analgesia and assisted vaginal delivery; and the neonatal variable of cranial circumference. The other variables did not affect the degree of laceration significantly. Table 2 shows the relative risk (as odds ratio values, OR) of laceration (any type), in relation to the maternal, obstetric and neonatal variables, after application of a multiple logistic regression model.

Multivariate analysis revealed that maternal age, position maintained during professional activity, BMI, use of oxytocin during the active phase of labor, time of membrane rupture, duration of the second period, locoregional analgesia and neonatal cranial circumference were not risk factors for perineal trauma. Primiparity, episiotomy and assisted vaginal delivery presented 2.7, 89 and 4.5-fold increased risk of perineal trauma, respectively.

Table 3 lists the relative risks of the maternal, obstetric and neonatal variables (as OR, obtained through multivariate logistic regression) for first and second-degree perineal tears. Multivariate analysis showed that maternal age, position maintained during professional activity, BMI, use of oxytocin during the active phase of labor, duration of the second stage, locoregional analgesia, neonatal cranial circumference and birth weight were not risk factors for first and second-degree perineal tears.
Primiparity, nonuse of episiotomy and use of assisted vaginal delivery presented 1.6, 10 and 2-fold higher risk of first and second-degree perineal trauma, respectively. Interestingly, membrane rupture that occurred between 12 and $18 \mathrm{~h}$ before delivery reduced the risk of perineal tears by almost 50\% (OR 0.54, 95\% confidence interval, CI: 0.31-0.94).

Table 4 summarizes the relative risks of the maternal, obstetric and neonatal variables for third and fourth-degree perineal traumas. None of the statistically significant variables for perineal trauma shown in Table 1 remained as risk factors after adjusted logistic regression. The exception was body position during professional activity, since pregnant women who remained in a standing position most of the time had a threefold higher risk of perineal trauma (OR 2.85; 95\% CI: 1.34-6.09). Table 5 shows the maternal and perinatal results. First and fifth-minute Apgar scores less than 7, meconium fluid present at the time of delivery, mechanical ventilation, neonatal death, bleeding disorders and postpartum maternal infection did not significantly impact the degree of laceration. We were unable to correlate dehiscence of episiotomy sutures with the degree of perineal laceration. No maternal deaths occurred among this sample. Patients with severe perineal trauma were at increased risk of remaining in the hospital for more than four days, compared with patients presenting mild or no perineal trauma.

\section{DISCUSSION}

We found that the prevalence of severe perineal tears (third and fourth-degree) was $0.9 \%$ in our cohort, which can be considered low in comparison with some previous studies ${ }^{14,15}$ but similar to or higher than values reported from other samples. ${ }^{16,17}$ For example, one study in the United States found a prevalence of severe laceration of $0.25 \%{ }^{18}$ Lack of a national database in Brazil prevents comparison of our results with those from other Brazilian regions. Misdiagnosis of perineal tears associated with inexperience among surgeons and inadequate surgical repair during the postpartum period may affect the prevalence of severe perineal trauma. Previous studies ${ }^{19,20}$ have shown that obstetrics-gynecology residents cannot identify OASIS properly, and therefore underreporting of these events may influence the recorded laceration patterns.

On the other hand, better prenatal care, ultrasonographic diagnosing of macrosomic fetuses, manual support of the perineum and selective use of mediolateral episiotomy (MLE) could explain the low incidence of perineal tears. Multivariate analysis in the present study revealed that the variable of MLE had a protective effect in relation to mild and severe perineal trauma, which means that it is possible for MLE to be used as a perineal protective maneuver during the second period of labor. However, the data on MLE in the literature are divergent. A retrospective study on 3,038 deliveries in a British hospital also showed that MLE was a protective factor against 
Table 1. Risk of perineal trauma presented by the variables studied

\begin{tabular}{|c|c|c|c|c|}
\hline & \multicolumn{3}{|c|}{ Perineal trauma } & \multirow{2}{*}{ P-value } \\
\hline & None (\%) & Mild (\%) & Severe $(\%)$ & \\
\hline$\leq 19$ & 29.4 & 20.0 & 25.9 & \multirow{2}{*}{$<0.0001$} \\
\hline$>35$ & 3.8 & 6.3 & 14.8 & \\
\hline \multicolumn{5}{|l|}{ Race } \\
\hline White & 65.2 & 63.5 & 52.9 & $>0.05$ \\
\hline Standing & 18.9 & 20.0 & 40.7 & \multirow{2}{*}{0.0149} \\
\hline Sitting & 81.1 & 80.0 & 59.3 & \\
\hline \multicolumn{5}{|l|}{ Use of tobacco and/or illicit drug } \\
\hline Yes & 15.1 & 15.7 & 11.1 & \multirow{2}{*}{$>0.05$} \\
\hline No & 84.9 & 84.3 & 88.9 & \\
\hline \multicolumn{5}{|l|}{ Body mass index } \\
\hline \multicolumn{5}{|l|}{ Maternal height (m) } \\
\hline$<1.50$ & 3.2 & 2.8 & 5.0 & \multirow{5}{*}{$>0.05$} \\
\hline $1.50-1.55$ & 18.6 & 19.4 & 35.0 & \\
\hline $1.56-1.60$ & 29.7 & 28.6 & 35.0 & \\
\hline $1.61-1.65$ & 28.9 & 29.6 & 20.0 & \\
\hline$>1.65$ & 19.6 & 19.6 & 5.0 & \\
\hline \multicolumn{5}{|l|}{ Previous vaginal delivery } \\
\hline Yes & 46.2 & 68.7 & 44.4 & \multirow{2}{*}{$<0.0001$} \\
\hline No & 53.8 & 31.3 & 55.6 & \\
\hline \multicolumn{5}{|l|}{ Use of oxytocin } \\
\hline Yes & 59.0 & 53.8 & 55.6 & 0.0183 \\
\hline Duration of the second period (min) & & & & \\
\hline$<30$ & 85.0 & 92.6 & 85.0 & \\
\hline $30-60$ & 9.2 & 5.1 & 5.0 & $<0.0001$ \\
\hline$>60$ & 5.8 & 2.3 & 10.0 & \\
\hline Episiotomy & & & & \\
\hline Yes & 58.8 & 4.9 & 29.6 & $<00001$ \\
\hline No & 41.2 & 91.1 & 70.4 & $<0.0001$ \\
\hline Locoregional analgesia & & & & \\
\hline Yes & 67.3 & 56.2 & 67.3 & \\
\hline No & 32.7 & 43.8 & 32.7 & $<0.0001$ \\
\hline Assisted vaginal delivery & & & & \\
\hline Yes & 9.1 & 2.3 & 14,8 & \\
\hline No & 90.9 & 97.7 & 85,2 & $<0.0001$ \\
\hline Fetal presentation & & & & \\
\hline Flexed head & 90.7 & 91.5 & 92.6 & \\
\hline Deflexed head & 9.3 & 8.5 & 7.4 & $>0.05$ \\
\hline Birth weight (g) & & & & \\
\hline$<2700$ & 12.5 & 10.0 & 12.5 & \\
\hline $2700-3800$ & 80.0 & 80.5 & 70.8 & $>0.05$ \\
\hline Cranial circumference $(\mathrm{cm})$ & & & & \\
\hline$\leq 33$ & 32.8 & 26.2 & 25 & \\
\hline$>33$ & 67.2 & 73.8 & 75 & 0.002 \\
\hline
\end{tabular}


Table 2. Relative risk of perineal trauma among the variables studied, after multivariate analysis

\begin{tabular}{|c|c|c|c|c|}
\hline & \multicolumn{2}{|c|}{ Crude } & \multicolumn{2}{|c|}{ Adjusted } \\
\hline & Odds ratio & $95 \% \mathrm{Cl}$ & Odds ratio & $95 \% \mathrm{Cl}$ \\
\hline$\leq 19$ versus $20-35$ & 0.46 & $(0.25-0.85)$ & 1.10 & $(0.51-2.39)$ \\
\hline \multicolumn{5}{|c|}{ Body position during professional activity } \\
\hline Standing versus sitting & 1.16 & $(0.89-1.51)$ & 1.01 & $(0.72-1.41)$ \\
\hline \multicolumn{5}{|l|}{ Body mass index } \\
\hline \multicolumn{5}{|l|}{ Previous vaginal delivery } \\
\hline No versus yes & 0.33 & $(0.27-0.42)$ & 2.67 & $(1.75-4.10)$ \\
\hline \multicolumn{5}{|l|}{ Use of oxytocin } \\
\hline Yes versus no & 0.69 & $(0.56-0.86)$ & 1.06 & $(0.74-1.52)$ \\
\hline \multicolumn{5}{|c|}{ Length of time with ruptured membranes $(\mathrm{h})$} \\
\hline $6-12$ versus $<6$ & 0.91 & $(0.66-1.27)$ & 1.19 & $(0.76-1.86)$ \\
\hline \multicolumn{5}{|l|}{ Episiotomy } \\
\hline No versus yes & 26.03 & $(18.13-37.37)$ & 88.96 & $(50.53-156.61)$ \\
\hline \multicolumn{5}{|l|}{ Locoregional analgesia } \\
\hline No versus yes & 2.02 & $(1.61-2.54)$ & 1.10 & $(0.79-1.53)$ \\
\hline \multicolumn{5}{|l|}{ Assisted vaginal delivery } \\
\hline Yes versus no & 0.28 & $(0.17-0.48)$ & 4.48 & $(2.20-9.11)$ \\
\hline \multicolumn{5}{|l|}{ Cranial circumference $(\mathrm{cm})$} \\
\hline$>33$ versus $\leq 33$ & 1.31 & $(1.03-1.65)$ & $(1.03-1.65)$ & $(0.81-1.58)$ \\
\hline
\end{tabular}

$\mathrm{Cl}=$ confidence interval.

Table 3. Relative risk of mild perineal trauma among the variables studied, after multivariate analysis

\begin{tabular}{|c|c|c|c|c|}
\hline & \multicolumn{2}{|c|}{ Crude } & \multicolumn{2}{|c|}{ Adjusted } \\
\hline & Odds ratio & $95 \% \mathrm{Cl}$ & Odds ratio & $95 \% \mathrm{Cl}$ \\
\hline \multicolumn{5}{|l|}{ Maternal age (years) } \\
\hline$\leq 19$ versus $20-35$ & 0.63 & $(0.54-0.74)$ & 1.12 & $(0.79-1.57)$ \\
\hline \multicolumn{5}{|c|}{ Body position during professional activity } \\
\hline Standing versus sitting & 1.04 & $(0.94-1.14)$ & 0.96 & $(0.81-1.14)$ \\
\hline \multicolumn{5}{|l|}{ Body mass index } \\
\hline \multicolumn{5}{|l|}{ Previous vaginal delivery } \\
\hline No versus yes & 0.63 & $(0.58-0.68)$ & 1.64 & $(1.33-2.04)$ \\
\hline \multicolumn{5}{|l|}{ Use of oxytocin } \\
\hline Yes versus no & 0.90 & $(0.83-0.97)$ & 1.03 & $(0.86-1.23)$ \\
\hline \multicolumn{5}{|c|}{ Length of time with ruptured membranes $(\mathrm{h})$} \\
\hline $6-12$ versus $<6$ & 1.03 & $(0.83-1.29)$ & 1.16 & $(0.77-1.75)$ \\
\hline$<30$ versus $>60$ & 1.77 & $(1.45-2.16)$ & 1.13 & $(0.77-1.68)$ \\
\hline \multicolumn{5}{|l|}{ Episiotomy } \\
\hline No versus yes & 5.27 & $(4.57-6.09)$ & 9.93 & $(7.41-13.31)$ \\
\hline \multicolumn{5}{|l|}{ Locoregional analgesia } \\
\hline No versus yes & 1.27 & $(1.17-1.37)$ & 1.05 & $(0.88-1.24)$ \\
\hline \multicolumn{5}{|l|}{ Assisted vaginal delivery } \\
\hline Yes versus no & 0.48 & $(0.39-0.60)$ & 2.04 & $(1.39-2.97)$ \\
\hline \multicolumn{5}{|l|}{ Cranial circumference $(\mathrm{cm})$} \\
\hline$>33$ versus $\leq 33$ & 1.17 & $(1.07-1.29)$ & 1.06 & $(0.90-1.26)$ \\
\hline \multicolumn{5}{|l|}{ Birth weight $(g)$} \\
\hline $2700-3800$ versus $<2700$ & 1.00 & $(0.87-1.15)$ & 1.03 & $(0.90-1.26)$ \\
\hline$>3800$ versus $<2700$ & 1.25 & $(1.02-1.54)$ & 1.01 & $(0.95-1.49)$ \\
\hline
\end{tabular}

$\mathrm{Cl}=$ confidence interval. 
Table 4. Relative risk of severe perineal trauma among the variables studied, after multivariate analysis

\begin{tabular}{|c|c|c|c|c|}
\hline & \multicolumn{2}{|c|}{ Crude } & \multicolumn{2}{|c|}{ Adjusted } \\
\hline & Odds ratio & $95 \% \mathrm{Cl}$ & Odds ratio & $95 \% \mathrm{Cl}$ \\
\hline \multicolumn{5}{|l|}{ Maternal age (years) } \\
\hline$\leq 19$ versus $20-35$ & 0.61 & $(0.33-1.14)$ & 0.96 & $(0.24-3.92)$ \\
\hline \multicolumn{5}{|c|}{ Body position during professional activity } \\
\hline Standing versus sitting & 1.72 & $(1.17-2.53)$ & 2.85 & $(1.34-6.09)$ \\
\hline Overweight versus normal & 1.16 & $(0.54-2.52)$ & 1.09 & $(0.33-3.55)$ \\
\hline \multicolumn{5}{|l|}{ Previous vaginal delivery } \\
\hline No versus yes & 1.04 & $(0.71-1.52)$ & 1.37 & $(0.48-3.95)$ \\
\hline \multicolumn{5}{|l|}{ Use of oxytocin } \\
\hline Yes versus no & 0.93 & $(0.64-1.36)$ & 1.45 & $(0.41-5.19)$ \\
\hline \multicolumn{5}{|l|}{ Second-stage duration (min) } \\
\hline $30-60$ versus $>60$ & 0.55 & $(0.14-2.24)$ & 0.74 & $(0.13-4.21)$ \\
\hline$<30$ versus $>60$ & 1.02 & $(0.43-2.43)$ & 1.19 & $(0.32-4.38)$ \\
\hline \multicolumn{5}{|l|}{ Episiotomy } \\
\hline No versus yes & 1.84 & $(1.22-2.79)$ & 2.60 & $(0.84-7.99)$ \\
\hline \multicolumn{5}{|l|}{ Locoregional analgesia } \\
\hline No versus yes & 0.93 & $(0.61-1.41)$ & 0.99 & $(0.40-2.46)$ \\
\hline \multicolumn{5}{|l|}{ Assisted vaginal delivery } \\
\hline Yes versus no & 1.32 & $(0.77-2.25)$ & 3.07 & $(0.98-9.60)$ \\
\hline \multicolumn{5}{|l|}{ Cranial circumference $(\mathrm{cm})$} \\
\hline
\end{tabular}

$\mathrm{Cl}=$ confidence interval.

Table 5. Maternal and neonatal outcomes from the population studied

\begin{tabular}{lcccc} 
& \multicolumn{3}{c}{ Perineal trauma } & \\
\cline { 2 - 3 } & $\begin{array}{c}\text { None } \\
(\mathbf{n}=1,902)\end{array}$ & $\begin{array}{c}\text { Mild } \\
(\mathbf{n}=1,105)\end{array}$ & $\begin{array}{c}\text { Severe } \\
(\mathbf{n}=\mathbf{2 7})\end{array}$ & P-value \\
Neonatal variables (\%) & & & & \\
$1^{\text {st }}$ minute Apgar $<7$ & 11.3 & 9.8 & 11.1 & 0.47 \\
$5^{\text {th }}$ minute Apgar $<7$ & 0.9 & 1.18 & 3.7 & 0.30 \\
Meconium fluid & 13.2 & 13.3 & 7.4 & 0.72 \\
Ventilatory support & 2.0 & 1.7 & 3.7 & 0.69 \\
Neonatal death & 0.3 & 0.3 & 0 & 0.50 \\
Maternal variables (\%) & & & & \\
Postpartum hemorrhage & 1.1 & 0.9 & 0 & 0.70 \\
Postpartum infection & 0.7 & 0.9 & 3.7 & 0.18 \\
\hline Hospitalization duration $>$ 4 days & 19.3 & 15.6 & 29.6 & 0.01 \\
\hline
\end{tabular}

severe perineal trauma, ${ }^{15}$ but another retrospective study including a larger number of deliveries $(n=168,077)$ found the opposite result ${ }^{21}$ and did not recommend prophylactic use of MLE. A Scandinavian group obtained different results when they separated 514,741 cases between primiparous and multiparous women: MLE was a protective factor for the former and a risk factor for the latter. ${ }^{22}$

One atypical finding from the present study was that the standing position during occupational activity is a risk factor for third and fourth-degree perineal trauma. Different body positions impact evaluations on the pelvic floor differently: basal vaginal pressure is higher while standing than while lying down. ${ }^{23}$ This affects the reliability of assessments on genital prolapse, because two-digit palpation correlates with prolapse symptoms when patients are examined in the standing position. ${ }^{24}$ Regarding pregnancy, associations between occupational activities (long working hours and prolonged standing periods) and unfavorable outcomes (prematurity and intrauterine growth restriction) are still a matter of controversy. ${ }^{25}$ Compared with the supine position, adopting a standing position during labor does not increase the risk of perineal trauma. ${ }^{26}$ To our knowledge, this variable has never been analyzed as an independent risk factor for perineal trauma. Studies on pelvic anatomy during and after 
birth labor have focused on assessment of changes that happen during the procedure; however, they have seldom evaluated factors that precede birth labor. Further studies are important for elucidating this issue.

We found an association between primiparity and mild perineal trauma. Several studies have reported a relationship between the first delivery and perineal tears. ${ }^{27,28}$ High pelvic muscle tone (not previously tested) may reduce vulvovaginal elasticity during the first and second labor stages, thus increasing the risk of perineal lesions.

We also observed that assisted vaginal delivery correlated with mild perineal trauma. Use of forceps may culminate in severe perineal trauma during fetal extraction, and so the obstetrician must be careful and experienced. Vacuum extraction delivery seems to lead to less perineal trauma than does forceps delivery. ${ }^{27}$

A length of time with ruptured membranes of between 12 and $18 \mathrm{~h}$ plays a protective role in relation to mild perineal trauma. It is hard to explain this finding, because preterm rupture of membranes results in birth labor that demands more analgesia, which in turn lessens the hydraulic cushion exerted by the amniotic fluid and impacts the pelviperineal region. ${ }^{29}$

The strengths of this study were its large sample, the great diversity of fetal-maternal variables and the possibility of analyzing new epidemiological variables (e.g. the standing position) that may influence future recommendations for preventing OASIS. The limitations of this study were its retrospective nature and the possibility that the professionals investigating OASIS might have underreported it. Estimates have shown that occult OASIS occurs in approximately 20-30\% of deliveries, and this should be discussed when healthcare professionals are being trained.

Finally, more prospective studies are necessary, in order to assess the risk factors associated with mild and severe perineal trauma. Standing position is a new risk factor that should be investigated in future studies. Further studies comparing types of episiotomy should be conducted, because of the findings that the mediolateral type has a protective role. It is important to identify women who are at risk of OASIS during birth labor, in order to minimize the risks of perineal trauma during this period. Obstetricians need to have advanced knowledge of pelviperineal anatomy, so as not to cause harm during labor.

\section{CONCLUSIONS}

The prevalence of perineal tears found in this study was concordant with data in the literature. The standing position was a risk factor for severe perineal trauma. Episiotomy presented a protective role, in comparison with other variables.

\section{REFERENCES}

1. Dudding TC, Vaizey CJ, Kamm MA. Obstetric anal sphincter injury: incidence, risk factors, and management. Ann Surg. 2008;247(2):224-37.

2. Williams A, Tincello DG, White $S$, et al. Risk scoring system for prediction of obstetric anal sphincter injury. BJOG. 2005; 112(8):1066-9.

3. Varma MG, Brown JS, Creasman JM, et al. Fecal incontinence in females older than aged 40 years: who is at risk? Dis Colon Rectum. 2006:49(6):841-51.

4. Kudish B, Sokol RJ, Kruger M. Trends in major modifiable risk factors for severe perineal trauma, 1996-2006. Int J Gynaecol Obstet. 2008;102(2):165-70.

5. Goldberg J, Hyslop T, Tolosa JE, Sultana C. Racial differences in severe perineal lacerations after vaginal delivery. Am J Obstet Gynecol. 2003;188(4):1063-7.

6. Richter HE, Brumfield CG, Cliver SP, et al. Risk factors associated with anal sphincter tear: a comparison of primiparous patients, vaginal births after cesarean deliveries, and patients with previous vaginal delivery. Am J Obstet Gynecol. 2002;187(5):1194-8.

7. Lowder JL, Burrows $\amalg$, Krohn MA, Weber AM. Risk factors for primary and subsequent anal sphincter lacerations: a comparison of cohorts by parity and prior mode of delivery. Am J Obstet Gynecol. 2007;196(4):344.e1-5.

8. Kabiru W, Raynor BD. Obstetric outcomes associated with increase in BMl category during pregnancy. Am J Obstet Gynecol. 2004;191(3):928-32.

9. Benavides L, Wu JM, Hundley AF, Ivester TS, Visco AG. The impact of occiput posterior fetal head position on the risk of anal sphincter injury in forceps-assisted vaginal deliveries. Am J Obstet Gynecol. 2005;192(5):1702-6.

10. McLeod NL, Gilmour DT, Joseph KS, Farrell SA, Luther ER. Trends in major risk factors for anal sphincter lacerations: a 10-year study. J Obstet Gynaecol Can. 2003;25(7):586-93.

11. Eriksson SL, Olausson PO, Olofsson C. Use of epidural analgesia and its relation to caesarean and instrumental deliveries-a population-based study of 94,217 primiparae. Eur J Obstet Gynecol Reprod Biol. 2006;128(1-2):270-5

12. Lieberman $\mathrm{E}, \mathrm{O}$ 'donoghue $\mathrm{C}$. Unintended effects of epidural analgesia during labor: a systematic review. Am J Obstet Gynecol. 2002;186(5 Suppl Nature):S31-68.

13. Carroli G, Mignini L. Episiotomy for vaginal birth. Cochrane Database Syst Rev. 2009;21(1):CD000081.

14. de Leeuw JW, Struijk PC, Vierhout ME, Wallenburg HC. Risk factors for third degree perineal ruptures during delivery. BJOG. 2001;108(4):383-7.

15. Eskandar O, Shet D. Risk factors for 3rd and 4th degree perineal tear. J Obstet Gynaecol. 2009;29(2):119-22.

16. Williams A. Third-degree perineal tears: risk factors and outcome after primary repair. J Obstet Gynaecol. 2003;23(6):611-4. 
17. Sheiner E, Levy A, Walfisch A, Hallak M, Mazor M. Third degree perineal tears in a university medical center where midline episiotomies are not performed. Arch Gynecol Obstet. 2005;271(4):307-10.

18. Groutz A, Hasson J, Wengier A, et al. Third- and fourth-degree perineal tears: prevalence and risk factors in the third millennium. Am J Obstet Gynecol. 2011;204(4):347e1-4.

19. Siddighi S, Kleeman SD, Baggish MS, et al. Effects of an educational workshop on performance of fourth-degree perineal laceration repair. Obstet Gynecol. 2007;109(2 Pt 1):289-94.

20. Fernando RJ, Sultan AH, Radley S, Jones PW, Johanson RB. Management of obstetric anal sphincter injury: a systematic review \& national practice survey. BMC Health Serv Res. 2002;2(1):9.

21. Steiner $N$, Weintraub AY, Wiznitzer A, Sergienko R, Sheiner $E$. Episiotomy: the final cut? Arch Gynecol Obstet. 2012;286(6):1369-73.

22. Räisänen SH, Vehviläinen-Julkunen K, Gissler M, Heinonen S. Lateral episiotomy protects primiparous but not multiparous women from obstetric anal sphincter rupture. Acta Obstet Gynecol Scand. 2009;88(12):1365-72.

23. Frawley HC, Galea MP, Phillips BA, Sherburn M, Bø K. Effect of test position on pelvic floor muscle assessment. Int Urogynecol J Pelvic Floor Dysfunct. 2006;17(4):365-71.

24. Digesu GA, Khullar V, Cardozo L, Robinson D. Inter-observer reliability of digital vaginal examination using a four-grade scale in different patient positions. Int Urogynecol J Pelvic Floor Dysfunct. 2008;19(9):1303-7.

25. Bonzini M, Coggon D, Palmer KT. Risk of prematurity, low birthweight and pre-eclampsia in relation to working hours and physical activities: a systematic review. Occup Environ Med. 2007;64(4):228-43.

26. Lawrence A, Lewis L, Hofmeyr GJ, Downswell T, Styles C. Maternal positions and mobility during first stage labours. Cochrane Database Syst Rev. 2009;(2):CD003934.

27. Christianson LM, Bovbjerg VE, McDavitt EC, Hullfish KL. Risk factors for perineal injury during delivery. Am J Obstet Gynecol. 2003;189(1):255-60.

28. Groutz A, Cohen A, Gold R, et al. Risk factors for severe perineal injury during childbirth: a case-control study of 60 consecutive cases. Colorectal Dis. 2011;13(8):e216-9.

29. Simhan HN, Canavan TP. Preterm premature rupture of membranes: diagnosis, evaluation and management strategies. BJOG. 2005;112 Suppl 1:32-7.

Acknowledgements: We would like to thank the Research Support Foundation of the State of São Paulo (Fundação de Amparo à Pesquisa do Estado de São Paulo, Fapesp) for the scientific initiation fellowships (process no. 11/02358-4) and financial support

Sources of funding: Research Support Foundation of the State of São Paulo (Fundação de Amparo à Pesquisa do Estado de São Paulo, Fapesp) for the scientific initiation fellowships (process no. 11/02358-4) and financial support

Conflict of interest: None
Date of first submission: May 5, 2013

Last received: August 30, 2013

Accepted: September 17, 2013

\section{Address for correspondence:}

Alessandra Cristina Marcolin

Av. Bandeirantes, $3.900-8 \circ$ andar

Monte Alegre — Ribeirão Preto (SP) — Brasil

CEP 14049-900

Tel. (+55 16) 3602-2804

E-mail:dralemar@uol.com.br 